\title{
Investigation of Twin Tunnel Deformation with Umbrella Grouting Protection \& NATM Tunneling using 3D Finite Element: Case Study Cisumdawu Tunnel
}

\author{
W. Wijaya ${ }^{1 *}$, P. P. Rahardjo ${ }^{2}$, A. Lim $^{3}$ \\ ${ }^{1 * 2,3}$ Civil Engineering Faculty, Parahyangan Catholic University \\ Email :wellywijaya24@gmail.com
}

\begin{tabular}{ll}
\hline A R T I C L E I N F O \\
\hline Article History & $:$ \\
Article entry & $: 13-08-2021$ \\
Article revised & $: 15-09-2021$ \\
Article received & $: 27-11-2021$ \\
\hline
\end{tabular}

Keywords :

Midas 3D, NATM, PMT, Tunnel,

Twin Tunnel, Umbrella Grouting.

IEEE Style in citing this article :

[1] E. Prahara, $M$. Suangga, and A. L. Ansori, "Analysis of potential diverted of passenger car to the new toll road (case study: Cileunyi - Sumedang, West Java), " IOP Conf. Ser. Earth Environ. Sci., vol. 109, no. 1, pp. 0-10, 2018, doi: $\quad 10.1088 / 1755-$ 1315/109/1/012043.

\section{Introduction}

Cisumdawu tunnel is the first toll road tunnel in Indonesia. The topographical
Cisumdawu Tunnel is a twin tunnel $472 \mathrm{~m}$ long located in Sumedang. Twin tunnel construction can cause additional ground settlement and tunnel deformation. The tunnel construction method used is the New Austrian Tunneling Method (NATM) and umbrella grouting protection system. The principle of NATM is to maximize surrounding soil capacity to support its weight and balance the stresses around the tunnel. Investigation of tunnel deformation is important to know tunnel structure behavior and avoid possible failure. This research aims to know tunnel deformation and the effect of twin tunnel construction on the deformation and ground settlement. The data used such as tunnel geometry, monitoring data, pressuremeter test, and the drilling test. The 3D analysis will be performed for a single tunnel and twin tunnel using Midas GTS-NX, and monitoring data will be used for verification analysis. The 3D FEM help to model the soil condition and construction stage according to the actual condition. The analysis results show the maximum tunnel deformation that occurs from the beginning of the tunnel construction is $12.64 \mathrm{~cm}$. If the deformation starts to be calculated following the monitoring reading time, after the excavation at the monitoring point, the maximum deformation of the analysis results is $3.3 \& 4.4 \mathrm{~cm}$, where the monitoring shows maximum deformation of $3.3 \& 4.3 \mathrm{~cm}$. Through the results, it can be said that the analysis using 3D FEM with pressuremeter test parameter represents actual conditions. Twin tunnel construction side-by-side increases ground settlement and lateral tunnel deformation significantly. Hence, it shows that tunnel analysis using 3D FEM recommends for future investigation of tunnel deformation.

Investigation of Twin Tunnel Deformation with Umbrella Grouting Protection \& NATM Tunneling using 3D Finite Element: Case Study Cisumdawu Tunnel 
condition of the road plan is the reason for the construction of the tunnel. The Cisumdawu Tunnel is part of the Cileunyi-Sumedang-Dawuan (Cisumdawu) Toll Road, precisely at STA. $12+628-13+100$ with a tunnel length of $472 \mathrm{~m}$ and diameter of $14 \mathrm{~m}$ located in Cilengser, Sumedang, West Java. The use of the Cisumdawu Toll Road can save travel time, reduce fuel consumption, pollution, and is expected to reduce national road maintenance costs [1].

There are hills in the initial plan of the road section to be built at STA. $12+628-$ $13+100$, so the tunnel was proposed. The tunnel construction uses the New Austrian Tunneling Method (NATM). This method is considered a suitable method for the soil conditions in this tunnel, which, based on the soil conditions, the tunnel is classified as a soft ground tunnel [2]. This type of tunnel is different from rock tunnels. During the excavation process, the tunnel tends to collapse, so roof protection is needed before the excavation process is carried out [3][4]. The construction of twin tunnels side by side results in the interaction effect of each tunnel when excavation is carried out in the form of tunnel deformation and ground settlement [5]. Therefore, the tunnel protection system must be able to reduce the deformation caused by the excavation of the tunnel and from the excavation of the adjacent tunnel.

The soil material around the tunnel has a low stand-up time, so that a support structure is needed before excavation is carried out. Stand-up time is the time when soil is in a stable state after excavation until it collapses. The tunnel protection system is strongly influenced by the stand-up time [6]. Ground Settlement during tunnel construction is caused by deformation in the tunnel area. This is very dependent on the construction method, excavation speed, and initial soil stress [7]. Other problems that may occur in tunnel construction such as dewatering problems, collapse in tunnel face during excavation, and leaks in the lining so that appropriate protection methods and systems are needed so that structural failure and tunnel stability can be avoided [8].

The tunnel protection system used in the Cisumdawu tunnel is the Umbrella Arch Method (UAM). The use of UAM can reduce the deformation that occurs in the tunnel and ground settlement due to excavation in the tunnel [9]. The UAM construction is carried out by making a shell-like curve through a pipe that is grouted around the tunnel before excavation is carried out to prevent collapse due to excavation. The use of UAM is effective for increasing soil stiffness and tunnel excavation stability [10]. UAM in Cisumdawu Tunnel is the first time in tunnel construction in Indonesia.

Analysis of tunnel deformation in this research using the 3D finite element method was carried out with the help of the Midas GTS-NX program. In the finite element analysis Investigation of Twin Tunnel Deformation with Umbrella Grouting Protection \& NATM Tunneling using 3D Finite Element: Case Study Cisumdawu Tunnel 
method, a problem is solved by dividing a unified system into smaller elements so as to provide a solution for each simpler element based on the concept of energy. The discretization pattern (Mesh) in the program is tetrahedral and octahedral for three-dimensional analysis.

A previous study was done in Cisumdawu tunnel by Dendi Yogaswara in 2019 using 2D finite element where the deformation of the 2D FEM modeling results is greater than the actual results in the field [2]. 2D modeling has limitations where it is difficult to model the existing soil conditions along the tunnel and model the construction phase according to actual construction. Therefore, in this study, 3D FEM analysis was carried out to describe the actual conditions in the field more specifically so that more accurate results were obtained.

Modeling the 3D finite element method using the MIDAS GTX-NX program is expected to describe the construction phase and deformation that occurs in the field. The aim of this paper is to know the deformation of twin tunnels using $3 \mathrm{D}$ finite element analysis and to find out the effect of twin tunnel construction on tunnel deformation and ground settlement compared with single tunnel construction.

\section{Research Method}

\subsection{Research Design}

The case study used in this research is Cisumdawu Tunnel with $14 \mathrm{~m}$ long that located in Cilengser, Sumedang, West Java. The Cisumdawu tunnel is a twin tunnel where there are two tunnels next to each other. The location and the front look of the Cisumdawu Tunnel can be seen in the following figure.

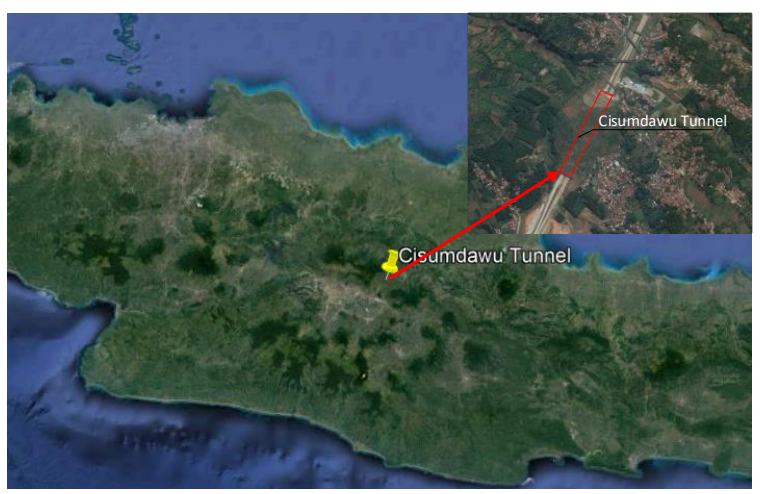

Source : Google Earth,2021

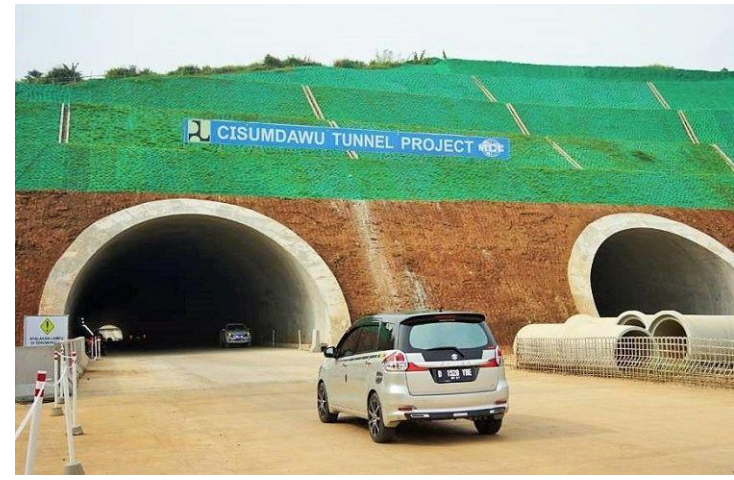

Source : Pikiran-rakyat.com (2020)

Figure 1. Location of Study (Cisumdawu Tunnel)

This research will be started by collecting soil data around the tunnel as well as the geometry and excavation methods used. After that, it was continued with a study of related research literature. Then through the collected soil data, soil parameters are taken to be used for analysis.

Investigation of Twin Tunnel Deformation with Umbrella Grouting Protection \& NATM Tunneling using 3D Finite Element: 
Using these data, 3D modeling was performed using the Midas GTS-NX program. The analysis in this study was carried out by single modeling tunnel and twin tunnel excavations to compare the deformations caused by twin tunnel excavations. The 3D FEM help to model the soil condition and construction stage according to the actual condition. Parameter used for analysis such as unit weight $(\gamma)$, unloading reloading modulus $\left(\mathrm{E}_{\mathrm{ur}}\right)$, friction angle $(\phi)$, cohesion $(\mathrm{c})$. The results of the twin tunnel analysis will be compared with the actual deformation results in the field and also compared to the twin tunnel analysis to determine the effect of twin tunnel construction on tunnel deformation and ground settlement.

\subsection{Soil Investigation and Design Parameter}

In this study, geotechnical design parameters were determined through the correlation of field test results such as SPT data and Pressuremeter test. The advantage of using the Pressuremeter Test (PMT) is that it can measure the existing soil stress (in-situ stress), in-situ soil modulus, and the relationship between soil stress-strain [11]. PMT testing produces reliable parameters for geotechnical design purposes and eliminates sample disturbances [12]. The stratification profile of the drilled soil in the tunnel area can be seen in the following figure.

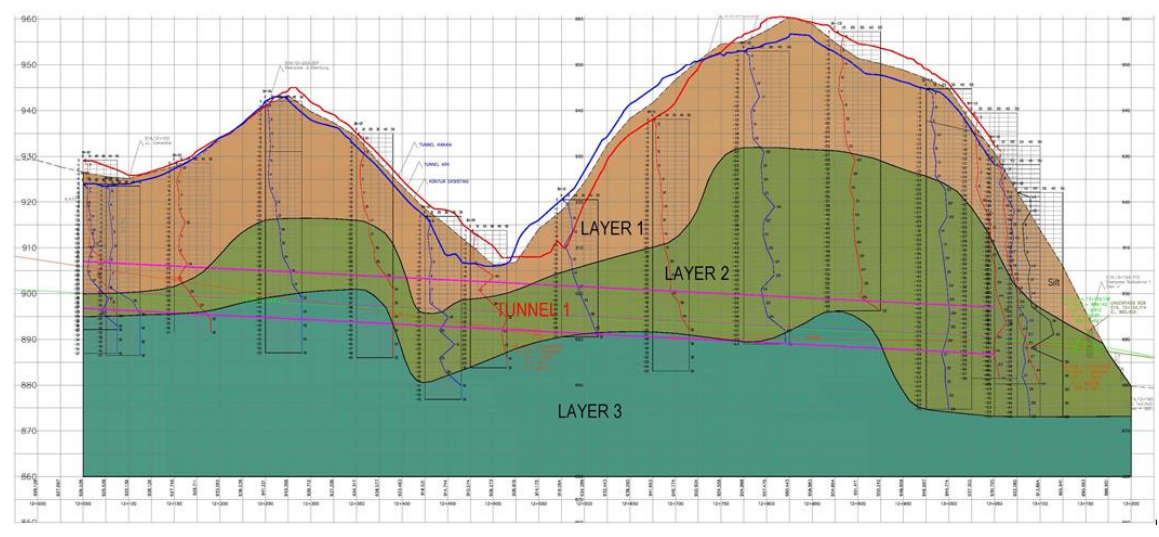

Source $\quad$ : Cisumdawu Tunnel GEC Final Report, 2013

Figure 2. Soil Profile in Tunnel Area

From the figure above, in general, the soil layer in the study area is dominated by 3 main layers, namely the first layer is a silty clay soil with medium to stiff consistency then followed by a very stiff clayey silt layer and until the end of the drilling, there is a clayey silt layer with a hard consistency. The correlation between the $\mathrm{N}$-spt value and the parameters from the PMT test results was used as a reference for taking design parameters. The correlation of the PMT test results and the N-spt value can be seen in Figure 3. 

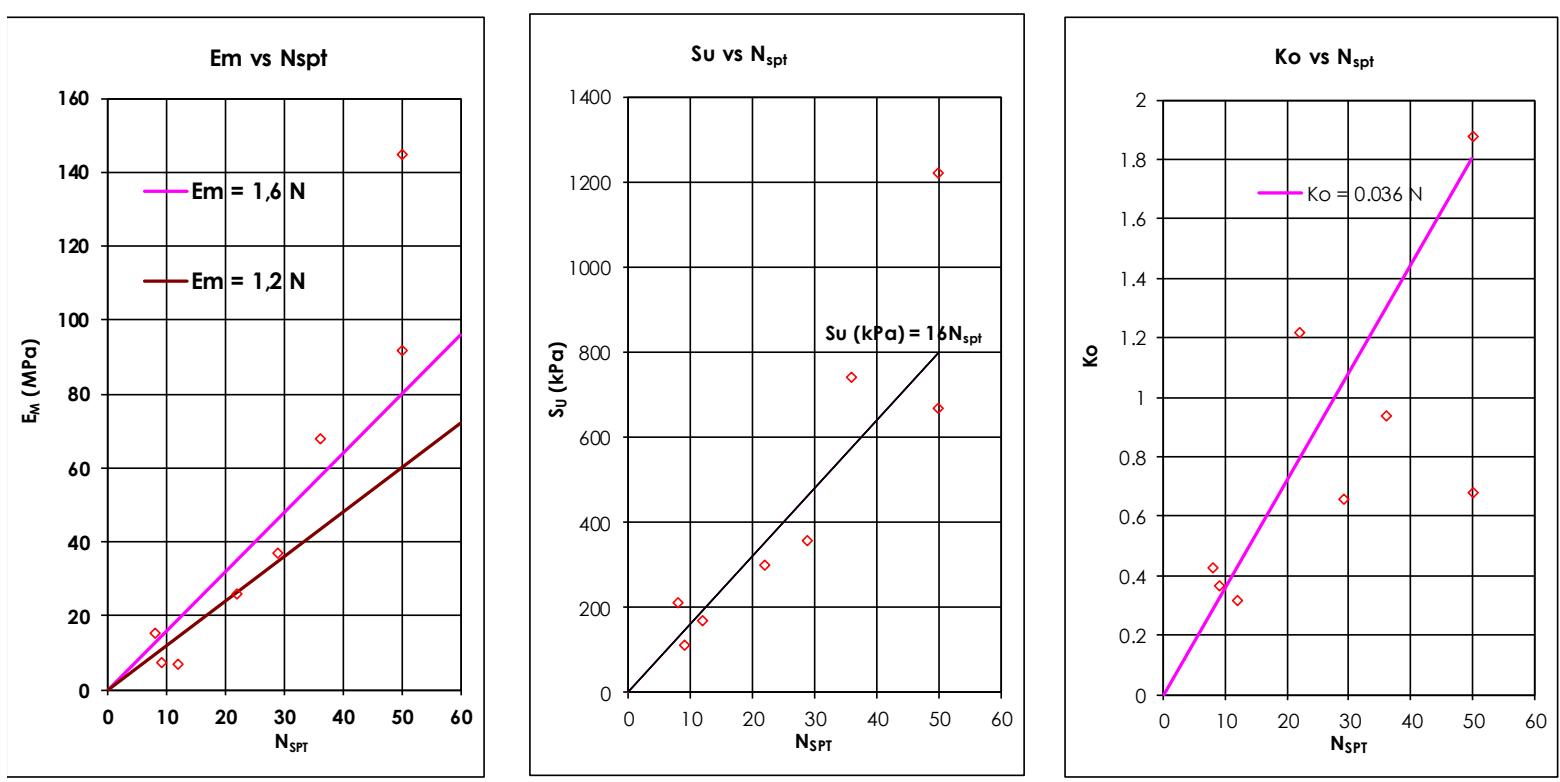

Source : Wellyanto Wijaya, 2021

Figure 3. Correlation of PMT Parameter and N-spt

Based on the correlation graph above, it is found that the greater the value of N-SPT, the greater the modulus elasticity of PMT $(\mathrm{Em})$, the undrained shear strength $(\mathrm{Su})$, and the coefficient at rest $(\mathrm{Ko})$. The correlation used is $\mathrm{Em}(\mathrm{MPa})=1.2 \mathrm{~N}$-spt and $\mathrm{Su}(\mathrm{kPa})=16 \mathrm{~N}$-spt. The modulus parameter used in the excavation case is the unloading reloading modulus (Eur) where is taken as $3 \mathrm{Em}$. The value of $\mathrm{c}^{\prime}$ is taken as $0.1 \mathrm{Su}$ [13]. A summary of the geotechnical design parameters used in this case can be seen in table 1 .

Table 1. Soil Parameter

\begin{tabular}{ccccccc}
\hline Layer & Soil Type & $\begin{array}{c}\gamma_{\text {unsat }} \\
{\left[\mathbf{k N} / \mathbf{m}^{3}\right]}\end{array}$ & $\begin{array}{c}\gamma_{\text {sat }} \\
{\left[\mathbf{k N} / \mathbf{m}^{3}\right]}\end{array}$ & $\begin{array}{c}\boldsymbol{\phi}^{\prime} \\
{\left[{ }^{\mathbf{}}\right]}\end{array}$ & $\begin{array}{c}\text { Su } \\
{[\mathbf{k P a}]}\end{array}$ & $\begin{array}{c}\text { Eur } \\
{[\mathbf{k P a}]}\end{array}$ \\
\hline 1 & 1. Medium Soil N=10 & 16 & 18 & 22 & 160 & 36000 \\
2 & 2. V Stiff Soil N=20 & 17 & 18 & 28 & 320 & 72000 \\
3 & 3. Hard Soil $>50$ & 20 & 22 & 35 & 800 & 180000 \\
\hline
\end{tabular}

Source : Wellyanto Wijaya (2021).

\subsection{Geological Condition}

According to Geological Map Bandung [14], Geological Cisumdawu Tunnel is undifferentiated young volcanic products that contain tuffaceous sand, lapilli, lava, agglomerate mostly from M. Tangkuban Perahu and Mount Tampomas. Soil condition in this area is expressed as a flat or low hill area covered by yellowish gray to reddish-gray soil. 


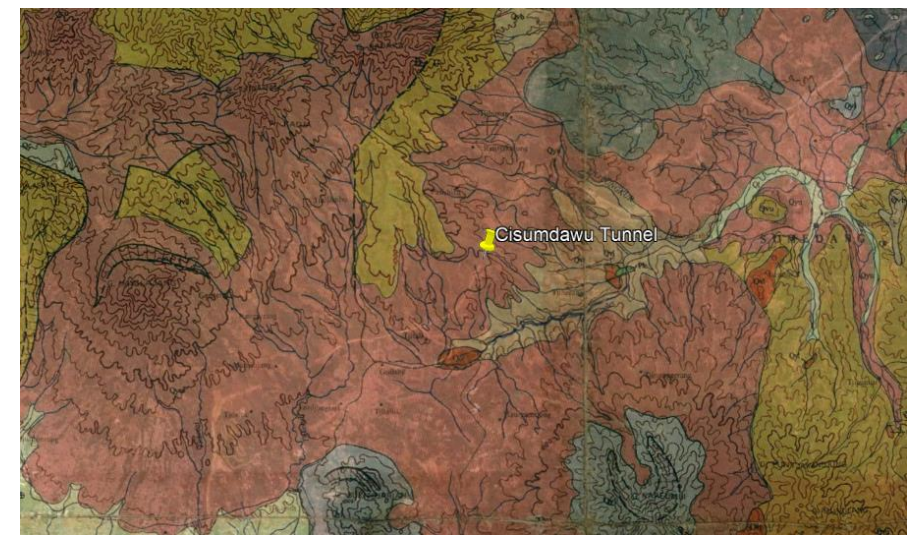

Source : Geological Map of Bandung Quadrangle, Java

Figure 4. Geological Map Study Location

\subsection{NATM and UAM Protection Design}

In this study, the construction method used was NATM where the method was developed in Austria in 1957 - 1965 by Ladislaus von Rabecwicz, Leopold Muller, and Franz Pacher. NATM is very suitable for tunnels with a length of less than $2 \mathrm{~km}$ in populated areas and mountainous areas [15][16]. The principle of the NATM is to maximize the capacity of the soil to support its own weight appropriately and rationally to balance the pressure affecting the surrounding rock and supporting structures to ensure stability at the face of the tunnel [17][18]. Continuous monitoring and visual observation of soil conditions and supporting structures are important components of the NATM [19].

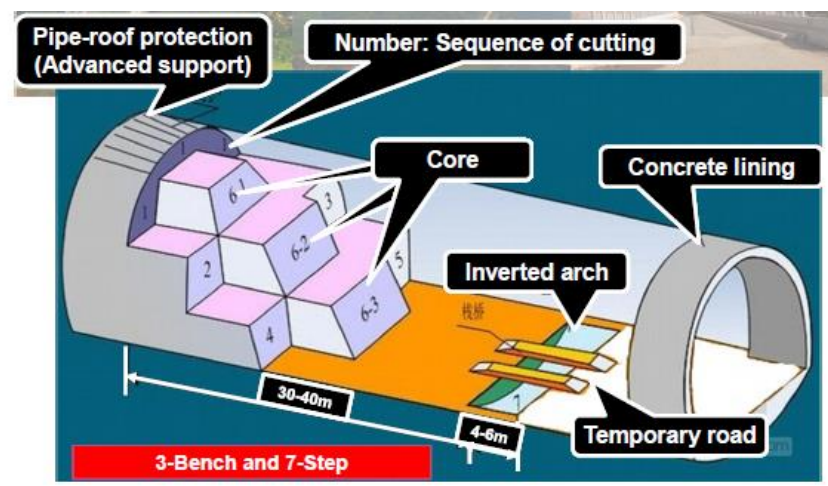

Source : Buna Marga Presentation Cisumdawu Tunnel, 2018

Figure 5. The Sequence of Excavation

Figure 5 shows the sequence of NATM excavation in this study consisting of 3 benches and 7 steps. The system protection used in this study is umbrella grouting or called the umbrella arch method (UAM). The protection method with UAM is constructed before the excavation is carried out by injecting a steel pipe that has been installed in the tunnel crown with a semi- 
circular pattern. This method reduces the stress concentration at the tunnel face and makes the tunnel more stable [20]. The steel pipe used in this study was $12 \mathrm{~m}$ long with ctc. $500 \mathrm{~mm}$, and dia. $114.3 \mathrm{~mm}$. The construction distance of each UAM is $9 \mathrm{~m}$, so that there is an overlap of 3 $\mathrm{m}$. The sketch of the UAM construction in the study can be seen in Figure 6. The use of UAM and NATM is based on several factors such as cost, soil conditions, tunnel geometry, allowable deformation, construction time, and quality of workers [21].
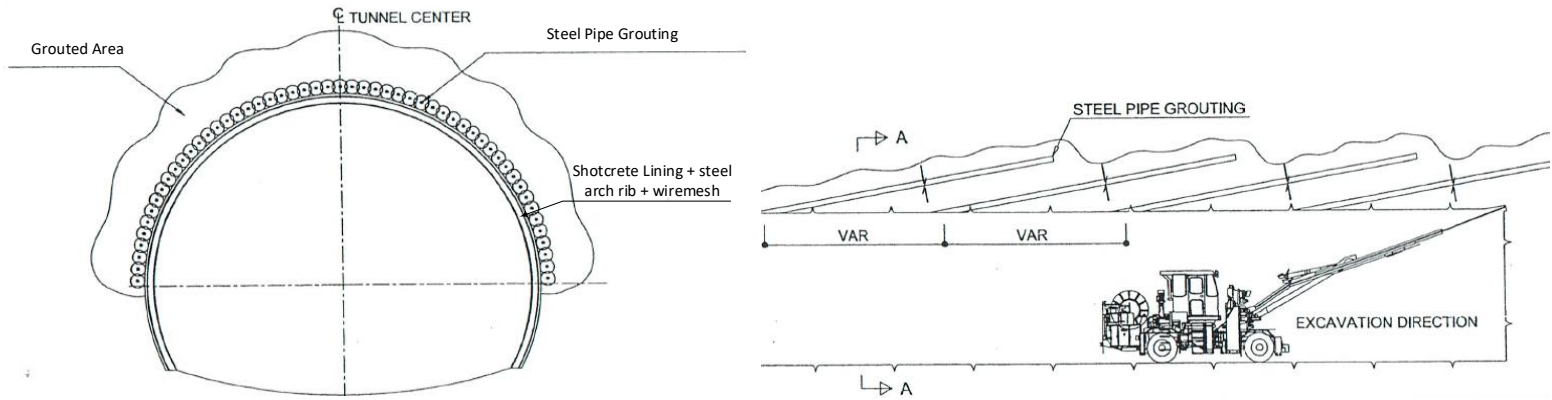

Source : Final Design Cisumdawu Tunnel, 2014

Figure 6. Sketch of Umbrella Arch Method

\subsection{D Finite Element Modeling (Midas GTS-NX)}

Analysis in this research was carried out using the 3D finite element method with the help of the Midas GTS-NX program. A finite element method is a numerical approach used to solve mechanical problems and other problems by dividing a system into smaller elements [22]. The modeling carried out is in the form of a staged construction analysis which is adjusted to the construction stage in the field. 3D FEM modeling takes a long time because it requires incremental phases to model the excavation stages [23]. The construction stages for the analysis are as follows:

1. Stage 1 : Initial Condition

2. Stage 2 : Installation of steel pipe and Umbrella Grouting

3. Stage 3 : Excavation sequence 1 from the beginning $(12+750)$ till $9 \mathrm{~m}$ (excavation stage every $1 \mathrm{~m}$ )

4. Stage 4 : Installation of lining + wire mesh + steel arch rib + shotcrete (every $1 \mathrm{~m}$ following excavation stage)

5. Stage 5 : Installation of steel pipe and Umbrella Grouting

6. Stage 6 : Excavation Sequence $1(9 \mathrm{~m}-18 \mathrm{~m})$, sequence 2,3,6-1 $(0-9 \mathrm{~m})$ every $1 \mathrm{~m}$

7. Stage 7: Installation of lining + wire mesh + steel arch rib + shotcrete (every $1 \mathrm{~m}$ following excavation stage)

8. Stage 8 : Installation of steel pipe and Umbrella Grouting

Investigation of Twin Tunnel Deformation with Umbrella Grouting Protection \& NATM Tunneling using 3D Finite Element: 
9. Stage 9 : Excavation Sequence $1(18 m-27 m)$, sequence 2,3,6-1 $(9-18 m)$, sequence 4,5,6-2 (0-9m) every $1 \mathrm{~m}$

10. Stage 10: Installation of lining + wire mesh + steel arch rib + shotcrete (every $1 \mathrm{~m}$ following excavation stage)

11. Stage 11: Installation of steel pipe and Umbrella Grouting

12. Stage 12 : Excavation sequence1 $(27 \mathrm{~m}-36 \mathrm{~m})$, sequence $2,3,6-1(18-27 \mathrm{~m})$, sequence 4,5,6-2 (9-18m), sequence 6-3 (0 -9m) every $1 \mathrm{~m}$,

13. Stage 13: Installation of lining + wire mesh + steel arch rib + shotcrete (every $1 \mathrm{~m}$ following excavation stage)

14. Stage 14: Installation of steel pipe and Umbrella Grouting

15. Stage 15 : Excavation Sequence 1 (36m - 45m), sequence 2,3,6-1 (27 - 36m), sequence 4,5,6-2 (18-27m), sequence 6-3 $(9-18 \mathrm{~m})$, sequence 7 invert $(0-9 \mathrm{~m})$ every $1 \mathrm{~m}$

16. Stage 16: Installation of lining + wire mesh + steel arch rib + shotcrete (every $1 \mathrm{~m}$ following excavation stage)

17. This step is repeated until the tunnel excavation is complete

In the Cisumdawu tunnel, the excavation was carried out from Sta 13+100 - 12+628, where the modeling in this study took the segment $12+750-12+660$. Three-dimensional (3D) modeling on Midas GTS NX can be seen in Figure 7. The soil profile in the modeling was adjusted to the soil investigation, which was dominated by 3 layers.
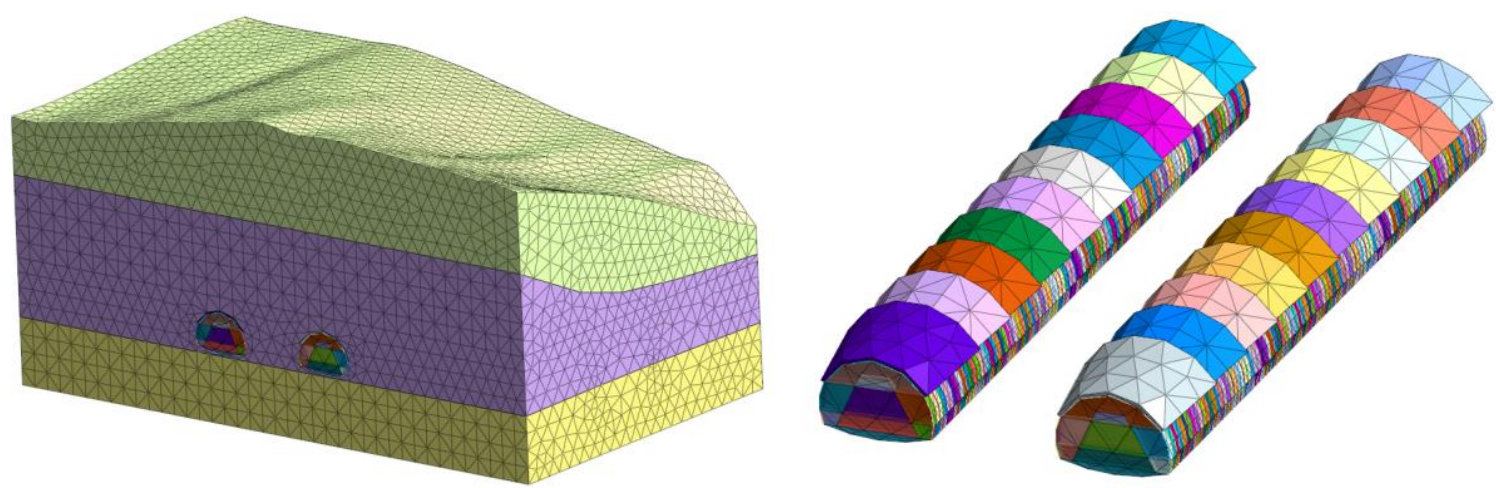

Source : Wellyanto Wijaya, 2021

Figure 7. 3D Model Finite Element (MIDAS GTS-NX)

\subsection{Monitoring Instrumentation}

Monitoring measurements on the tunnel profile are very important during the construction period following NATM principles. Monitoring of tunnel deformation during the excavation process aims to ensure the tunnel structure behavior same as design and avoids 
possible failures that occur [24]. The monitoring data used as verification of the analysis results are 2 monitoring points of the Right Tunnel in the STA. $12+702$ and STA. $12+722$. The installation of the monitoring point is carried out after the excavation at the monitoring point has been completed so that the immediate roof settlement is not measured. Monitoring begins after excavation is carried out 1 - 3 meters from the monitoring point, and the reading frequency is adjusted to the time the excavation work is carried out [25]. The 2 monitoring reading point in the modeling can be seen in Figure 8.
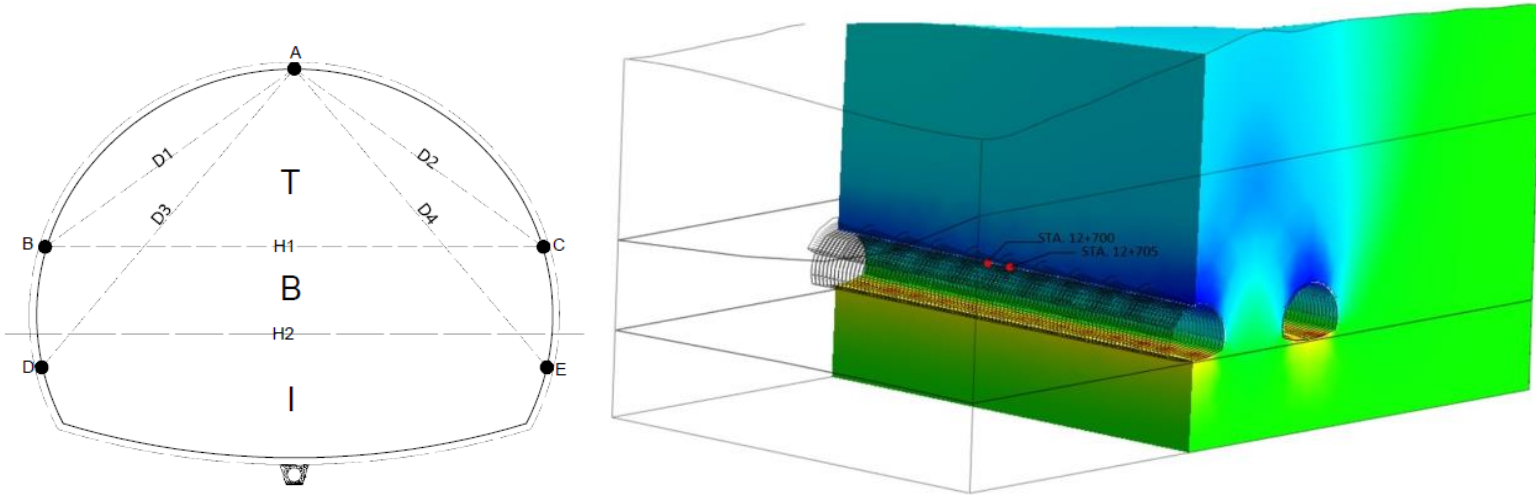

Source : Tunnel Monitoring Report, 2018

Figure 8. Monitoring Point (STA. $12+700$ and STA 12+705)

\subsection{Comparison Analysis Result}

The analysis results will be verified by comparing the roof settlement analysis results and the roof settlement monitoring, where the initial reading will be adjusted from the monitoring readings. Then a single tunnel analysis will be carried out to determine the effect of twin tunnel construction on tunnel deformation and settlement.

\section{Results and Discussions}

\subsection{Twin Tunnel Analysis}

The result of the twin tunnel analysis in this research showed that the maximum roof settlement that occurred in the tunnel until the excavation was completed was $12.64 \mathrm{~cm}$, while the maximum lateral deformation was $4.5 \mathrm{~cm}$. The contour of the deformation and settlement that occurs in the tunnel can be seen in Figure 9 and Figure 10. From the figure, it can be seen that the maximum deformation occurred in the front roof of the tunnel (STA 12+750). This is caused by the effect of the subsequent excavation of the tunnel on the deformation of the face of the tunnel that has been excavated. 

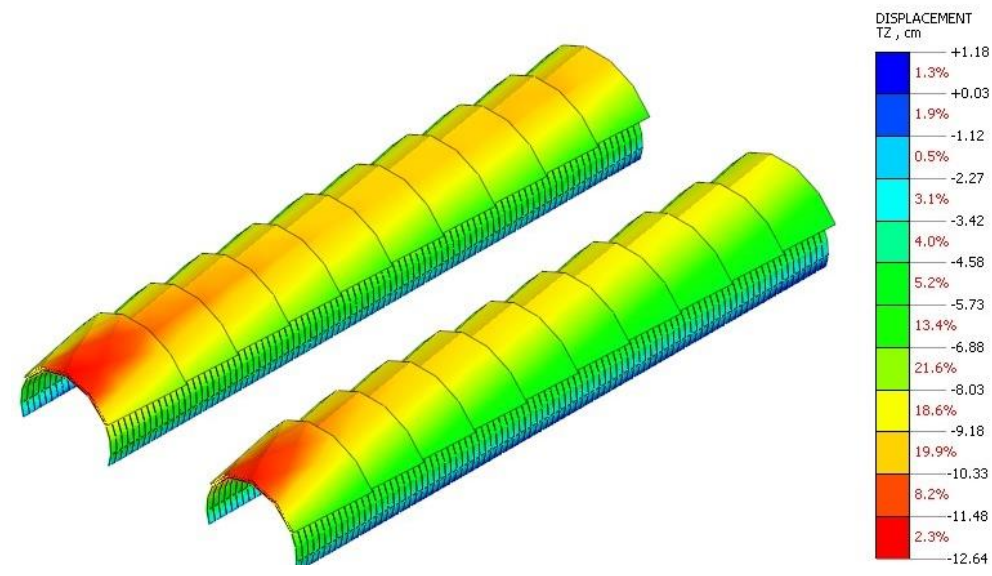

Source

: Wellyanto Wijaya, 2021

Figure 9. Tunnel Displacement in Z- Direction Twin Tunnel Analysis
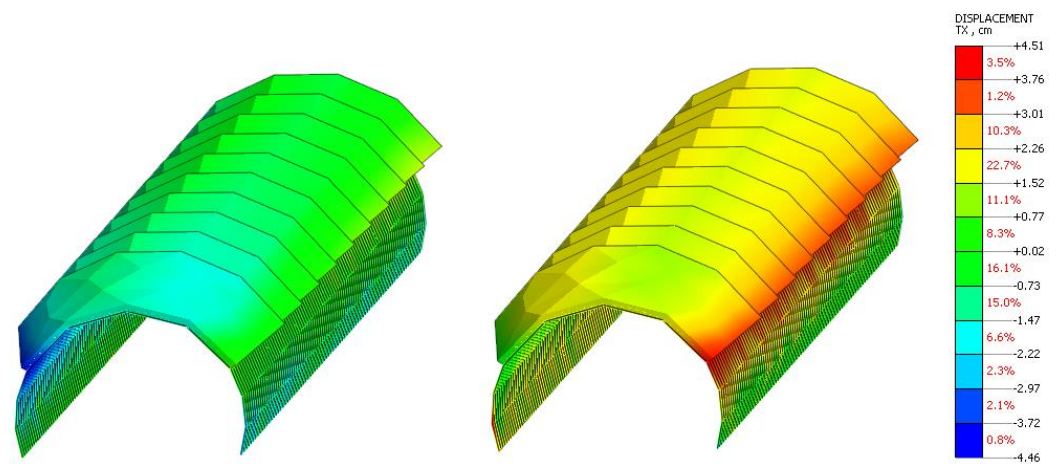

Source : Wellyanto Wijaya, 2021

Figure 10. Tunnel Displacement in X-direction Twin Tunnel Analysis

The results of the $3 \mathrm{D}$ analysis with twin tunnel modeling show that the maximum ground settlement that occurs is $7.7 \mathrm{~cm}$. The contour of the total displacement that occurs can be seen in Figure 11. From the figure, it can be seen that maximum ground settlement occurs in the between of the twin tunnel.

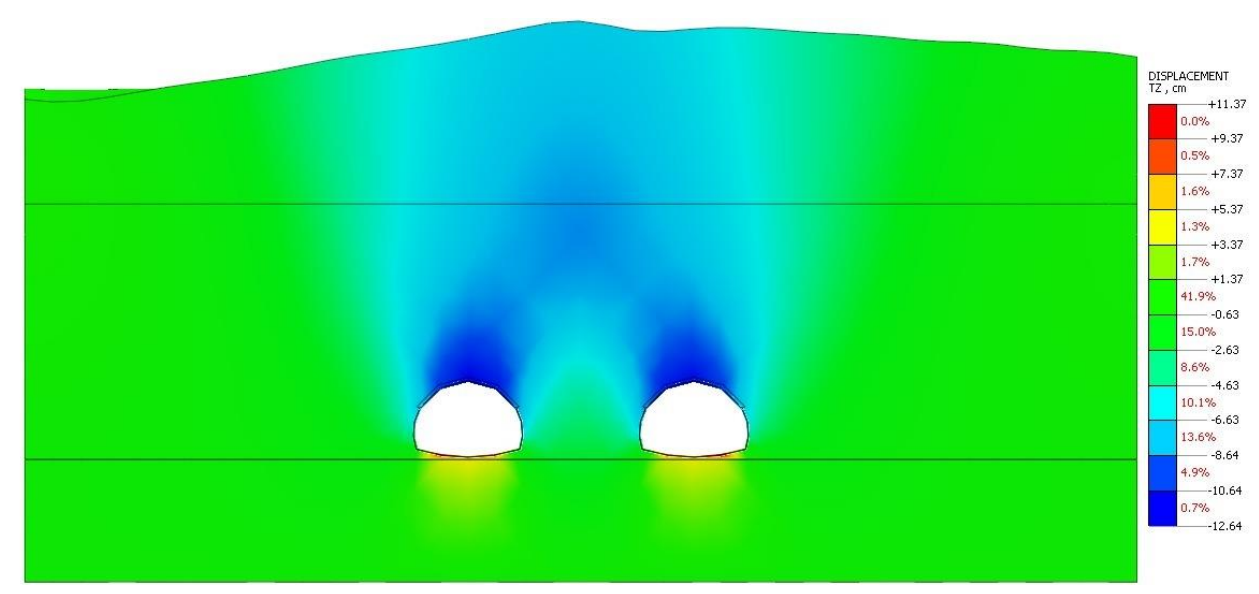

Source : Wellyanto Wijaya, 2021

Figure 11. The contour of Displacement Twin Tunnel Analysis

Investigation of Twin Tunnel Deformation with Umbrella Grouting Protection \& NATM Tunneling using 3D Finite Element: 


\subsection{Single Tunnel Analysis}

The result of the single tunnel analysis in this research showed that the maximum roof settlement that occurred in the tunnel until the excavation was completed was $12.01 \mathrm{~cm}$, and the maximum lateral deformation was $3.2 \mathrm{~cm}$. The contour of the deformation and settlement contour that occurs in the tunnel can be seen in Figure 12 and Figure 13.
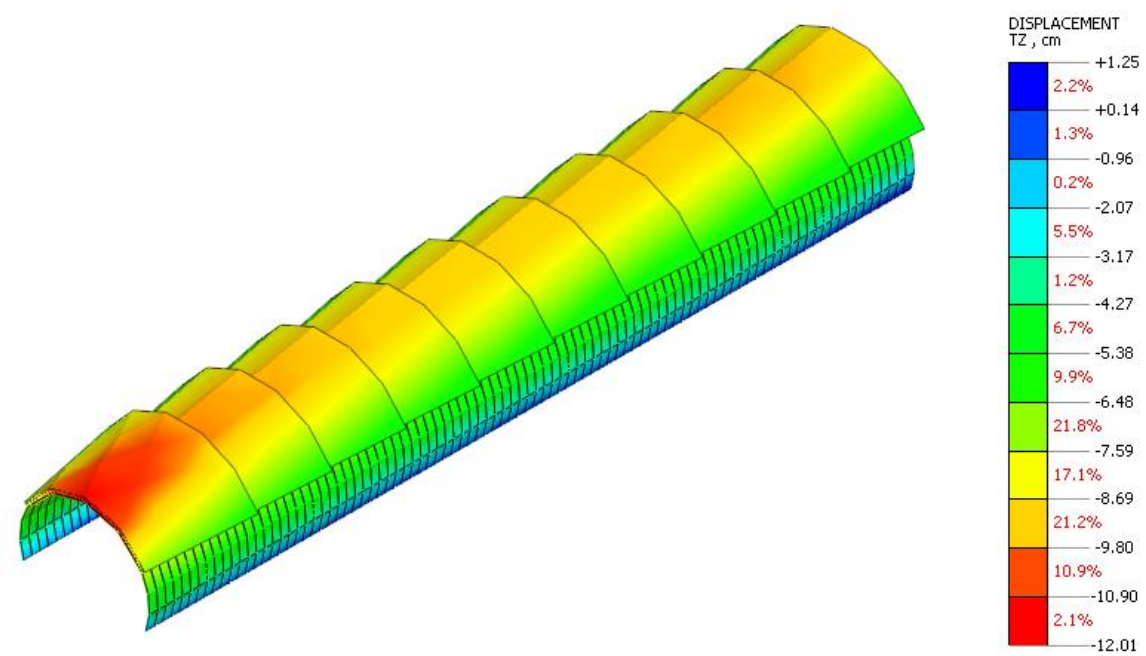

Source : Wellyanto Wijaya, 2021

Figure 12. Tunnel Displacement in Z- Direction SingleTunnel Analysis
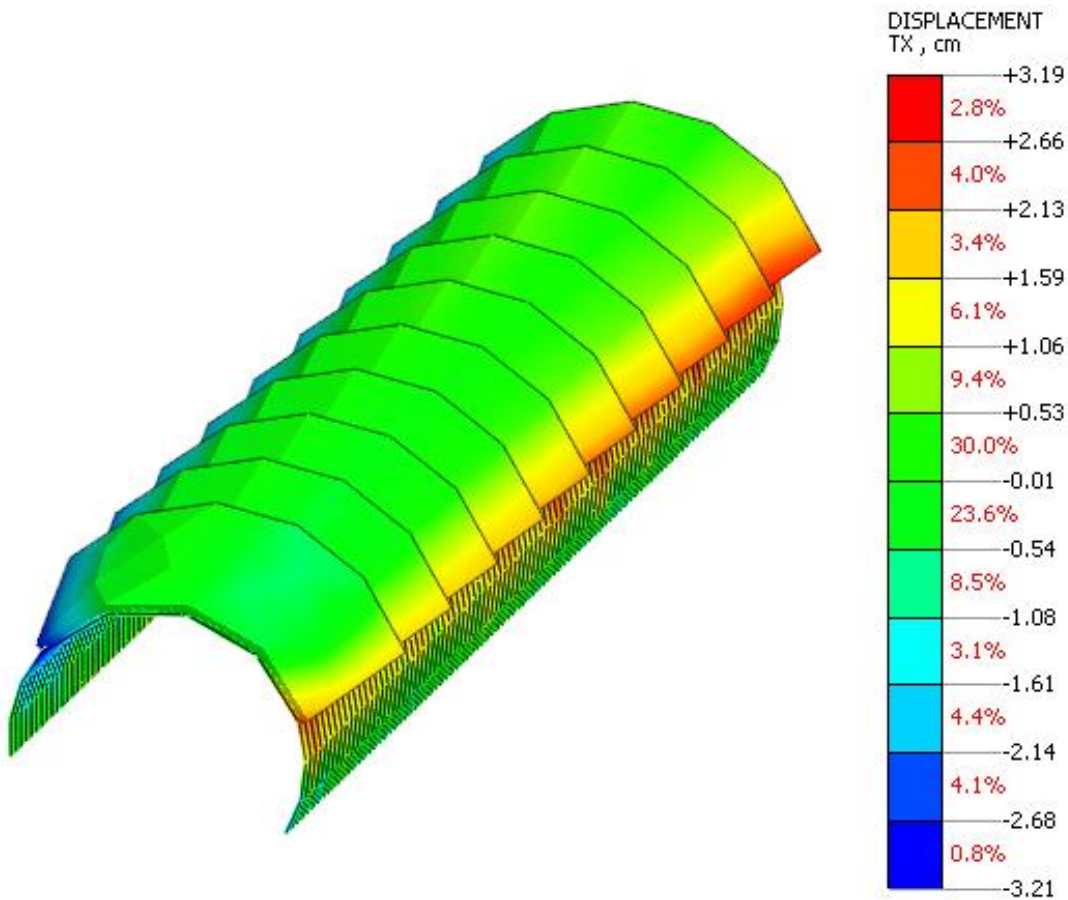

Source : Wellyanto Wijaya, 2021

Figure 13. Tunnel Displacement in X-direction Single Tunnel Analysis

The results of $3 \mathrm{~d}$ analysis with single tunnel excavation show that the maximum ground settlement that occurs is $4.6 \mathrm{~cm}$. The contour of the total displacement that occurs can be seen in Figure 14. The maximum ground settlement occurs at the top of the excavated tunnel. Investigation of Twin Tunnel Deformation with Umbrella Grouting Protection \& NATM Tunneling using 3D Finite Element: Case Study Cisumdawu Tunnel 


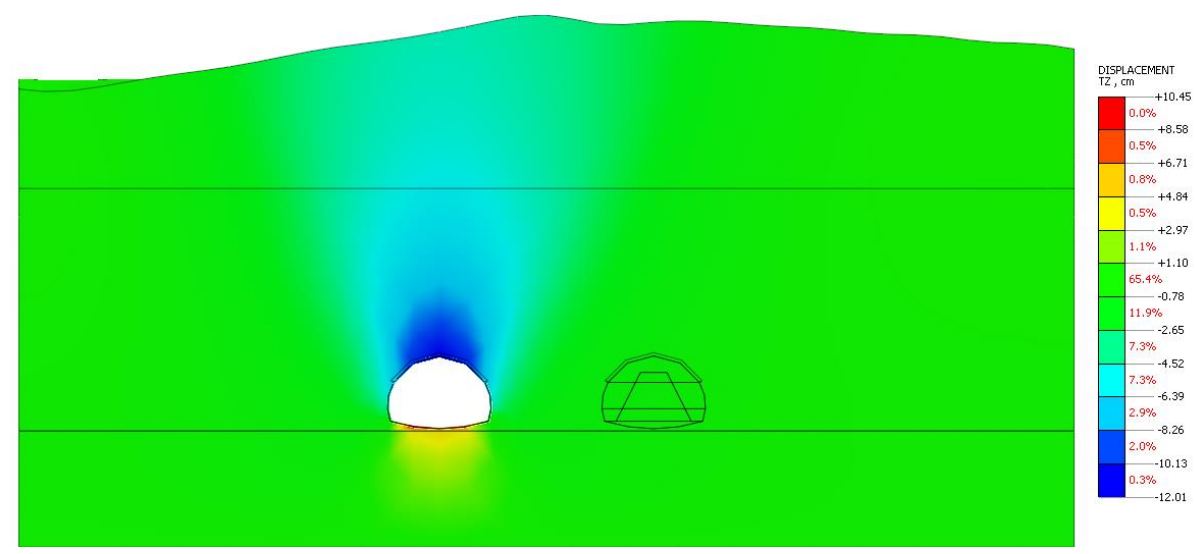

Source : Wellyanto Wijaya, 2021

Figure 14. The contour of Displacement Twin Tunnel Analysis

\subsection{Verification Analysis and Discussion}

\section{- $\quad$ Comparison Twin Tunnel Analysis \& Monitoring Data}

Based on the 3-dimensional analysis that has been carried out, verification of the results of the twin tunnel analysis is carried out with monitoring results. Monitoring readings begin after excavation at the monitoring point is carried out so that the immediate roof settlement due to excavation at that point is not measured. The settlement reading of the analysis result is adjusted to the monitoring reading time. The comparison of the results of $3 \mathrm{~d}$ analysis and monitoring can be seen in the following graph.

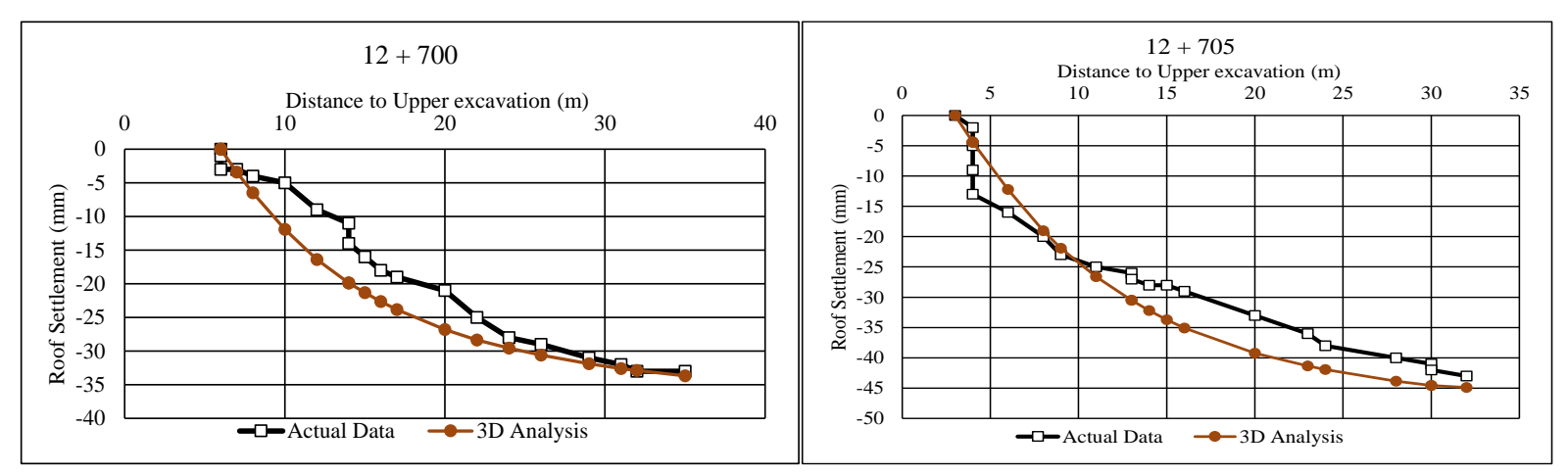

\section{Source : Wellyanto Wijaya, 2021}

Figure 15. Comparison 3D analysis with Monitoring Data STA $12+700 \&$ STA $12+705$

The graph above shows that the results of the $3 \mathrm{~d}$ analysis are similar to the results of the monitoring that has been carried out, with the roof settlement value from the monitoring readings being $3.3 \mathrm{~cm} \& 4.3 \mathrm{~cm}$, and the analysis results are $3.3 \mathrm{~cm} \& 4.4 \mathrm{~cm}$. The deformation value is still within the allowable deformation of $20 \mathrm{~cm}$. Based on the comparison results, it can be concluded that 3D analysis using Midas GTS-NX with parameters from PMT test is reliable for design analysis. 


\section{- Comparison Twin Tunnel Analysis \&Single Tunnel Analysis}

The results of the analysis show that there is an effect due to the adjacent tunnel construction on tunnel deformation and ground settlement. The summary of the deformation around the tunnel from twin tunnel and single tunnel analysis is shown in the table below.

Table 2. $\quad$ Summary of Analysis Result

\begin{tabular}{cccc}
\hline Analysis & $\begin{array}{c}\text { Maximum Settlement } \\
\text { of Tunnel } \\
{[\mathbf{c m}]}\end{array}$ & $\begin{array}{c}\text { Maximum Lateral } \\
\text { Deformation of Tunnel }\end{array}$ & $\begin{array}{c}\text { Ground } \\
\text { Settlement } \\
{[\mathbf{c m}]}\end{array}$ \\
\hline Twin Tunnel & 12.64 & 4.5 & 7.7 \\
Single Tunnel & 12.01 & 3.2 & 4.6
\end{tabular}

Source : Wellyanto Wijaya (2021)

From this table, it can be seen that the construction of two adjacent tunnels causes additional ground settlement as much as $3.1 \mathrm{~cm}(67 \%)$ and horizontal deformation as much as $1.3 \mathrm{~cm}(40 \%)$.

\section{Conclusion}

Analysis has been done for Cisumdawu Tunnel with NATM and Umbrella Grouting protection using 3d finite element Midas GTS-NX. Based on the analysis that has been done, there are several conclusions as follows:

a. The twin tunnel analysis result shows that the maximum roof settlement that occurred in the tunnel until the excavation was completed was $12.64 \mathrm{~cm}$ while the maximum lateral deformation was $4.5 \mathrm{~cm}$, while the single tunnel analysis results show the maximum roof settlement is $12.01 \mathrm{~cm}$ and the maximum lateral deformation is $3.2 \mathrm{~cm}$.

b. The comparison of the twin tunnel analysis and monitoring shows that the results of the $3 \mathrm{~d}$ analysis are similar to the results of the monitoring, with the roof settlement value from the monitoring readings being $3.3 \mathrm{~cm} \mathrm{\&} 4.3 \mathrm{~cm}$, and the analysis results are 3.3 $\mathrm{cm} \& 4.4 \mathrm{~cm}$. Parameter from pressuremeter test gives reliable results on Cisumdawu Tunnel Analysis with 3d finite element Midas GTS-NX

c. By comparing single tunnel and twin tunnel analysis, it can be concluded that the construction of two tunnels side by side significantly causes additional ground settlement as much as $3.1 \mathrm{~cm}(67 \%)$ and horizontal deformation as much as $1.3 \mathrm{~cm}$ $(40 \%)$

\section{Acknowledgments}

This paper is supported by P.T. Geotechnical Engineering Consultant that provides the license of Midas GTS-NX software used in this paper. 


\section{References}

[1] E. Prahara, M. Suangga, and A. L. Ansori, "Analysis of potential diverted of passenger car to the new toll road (case study: Cileunyi - Sumedang, West Java)," IOP Conf. Ser. Earth Environ. Sci., vol. 109, no. 1, pp. 0-10, 2018, doi: 10.1088/17551315/109/1/012043.

[2] D. Yogaswara, “Analisis Terowongan Jalan Raya Dengan Proteksi Umbrella Grouting Menggunakan Metode Elemen Hingga 2D Kasus Studi Tol Cisumdawu,” J. Sains dan Teknol. ISTP, vol. 11, no. 02, pp. 137-147, 2019.

[3] S. V. Rori, S. Balamba, and A. N. Sarajar, "Analisa Tanah Pada Bukaan Terowongan (Studi Kasus: Terowongan Kawasan Green Hill, Madendeng),” J. Sipil Statik, vol. 5, no. 6, pp. 313-323, 2017.

[4] P. P. Rahardjo, Teknik Terowongan. Bandung: Geotechnical Engineering Center, 2010.

[5] A. Pedro, T. Cancela, J. A. e S. Sousa, and J. Grazina, "Deformations caused by the excavation of twin tunnels," Geotech. Asp. Undergr. Constr. Soft Gr. Geotech. Asp. Undergr. Constr. Soft Gr., pp. 203-214, 2018.

[6] R. Schuerch, R. Poggiati, P. Maspoli, and G. Anagnostou, "Design Charts for Estimating Face Stand-Up Time in Soft Ground Tunnelling," $2^{\text {nd }}$ International Conference on Tunnel Boring Machines in Difficult Grounds, TBM Digs Istanbul, 2016.

[7] R. B. Peck, "Deep Excavations and Tunneling in Soft Ground," Proc. 7th Int. Conf. soil Mech. Found. Eng., vol. 3, pp. 225-290, 1969.

[8] A. S. Dastjerdi, "Solutions for Tunneling Problems," First Natl. Conf. Environ. Energy Biodefense, 2014.

[9] M. Ranjbarnia, N. Rahimpour, and P. Oreste, "A simple analytical approach to simulate the arch umbrella supporting system in deep tunnels based on convergence confinement method," Tunn. Undergr. Sp. Technol., vol. 82, no. July, pp. 39-49, 2018, doi: 10.1016/j.tust.2018.07.033.

[10] A. Morovatdar, M. Palassi, and R. S. Ashtiani, "Effect of pipe characteristics in umbrella arch method on controlling tunneling-induced settlements in soft grounds," J. Rock Mech. Geotech. Eng., vol. 12, no. 5, pp. 984-1000, 2020, doi: 10.1016/j.jrmge.2020.05.001.

[11] P. P. Rahardjo, Penyelidikan Geoteknik Dengan Uji In-Situ. Bandung: Geotechnical Engineering Center, 2008.

Investigation of Twin Tunnel Deformation with Umbrella Grouting Protection \& NATM Tunneling using 3D Finite Element: 
[12] R. Sundaram, S. Gupta, S. Gupta, and B. Lal, "Geotechnical design parameters for a metro tunnel from pressuremeter tests," Int. Symp. Geotech. Transp. Infrastruct. ISGTI2018, pp. 400-404, 2018, doi: 10.1007/978-981-13-6713-7_5.

[13] K. K. Sorensen, K. K. Sorensen, and N. Okkels, "Correlation between drained shear strength and plasticity index of undisturbed overconsolidated clays Correlation between drained shear strength and plasticity index of undisturbed overconsolidated clays Corrélation entre la résistance au cisaillement des," no. December, pp. 423-428, 2013.

[14] P. H. Silitonga, “Geological map of the Bandung Quadrangle," 1973.

[15] D. Pandit and U. Patel, "New austrian tunneling method," no. 10, India, Jan. 2021.

[16] A. Thomas, Sprayed Concrete Lined Tunnels-2nd edition. Abingdon, U.K.: Taylor and Francis, 2019.

[17] M. Karakus and R. Fowell, "An Insight into the New Austrian Tunneling Method," in 7th Regional Rock Mechanics Symposium, ROCKMEC, 2004, p. 14.

[18] E. B. Aygar, "Evaluation of new Austrian tunnelling method applied to Bolu tunnel's weak rocks," J. Rock Mech. Geotech. Eng., vol. 12, no. 3, pp. 541-556, 2020, doi: 10.1016/j.jrmge.2019.12.011.

[19] D. Chapman, N. Metje, and A. Stark, Introduction to Tunnel Construction. New York: Spon Press, 2010.

[20] A. Rostami, P. K. Dehkordi, M. A. Ziarati, S. Jahani, and K. Lotfi, "The Types of Tunnels Maintenance in Umbrella Arch Method," Open J. Civ. Eng., vol. 06, no. 02, pp. 156-162, 2016, doi: 10.4236/ojce.2016.62014.

[21] I. Ocak and E. Selcuk, "Comparison of NATM and umbrella arch method in terms of cost, completion time, and deformation," Arab. J. Geosci., vol. 10, no. 7, 2017, doi: $10.1007 / \mathrm{s} 12517-017-2938-8$.

[22] C. Girsang, R. P.P., and A. Lim, "Investigation of Pile Behavior Toward Abutment Construction using PLAXIS 3D: Case Study on Lembak Bridge," U KaRsT, vol. 5, pp. 1-16, 2021, doi: http://dx.doi.org/10.30737/ukarst.v3i2.

[23] E. Ağbay and T. Topal, "Evaluation of twin tunnel-induced surface ground deformation by empirical and numerical analyses (NATM part of Eurasia tunnel, Turkey)," Comput. Geotech., vol. 119, no. May 2019, 2020, doi: 10.1016/j.compgeo.2019.103367.

[24] B. S. Nasional, SNI 8460:2017 Persyaratan Perancangan Geoteknik. Indonesia, 2017.

[25] P.T.CECI, “Tunnel Monitoring and MeasureMonthly Report No. 16,” Indonesia, 2018. 